\title{
MORPHOLOGICAL AND ANALYTIC CAUSATIVE CONSTRUCTION IN DELI JAVANESE DIALECT
}

\author{
Zuindra, Mulyadi \\ Universitas Sumatera Utara, Medan, Indonesia \\ E-mail: zuindraidris@gmail.com
}

Received: 15 January 2020

Accepted: 06 May 2020

\begin{abstract}
This article discusses causative construction of Deli Javanese dialect which focuses on morphological and analytic causative construction. This study aims to reveal how morphological and analytic causative constructions in Deli Javanese dialect are formed. The theory of causative construction concept is based on Comrie (1989). The research data were obtained from text books, journals and interview. The causative construction in this analysis was elaborated by using tree diagram. The result showed that the morphological causative construction of Deli Javanese dialect utilized the verbs, which were shown by prefixes and suffixes. The causative construction in the verb nggodoke 'boil something for somebody' is derived from nggodok 'boil'; thus, it is indicated by the suffix $-e$. Meanwhile, the analytic causative construction utilized nggawe 'make' in which it indicates an action with desire. Furthermore, Analytic causative construction in Deli Javanese dialect is a clause construction, which has two predicates. This research finally provides some contributions and references for any further research related to the causative construction within any languages.
\end{abstract}

Keywords: Javanese dialect, causative construction, morphological causative, analytic causative.

\section{Introduction}

The types of causative constructions that each language has are different from one language to another. At least there are three ways to express causation: analytic causative, morphological causative and lexical causative (Comrie, 1989). Some languages have all the three types of causative constructions and some others have only two types of causative construction such as lexical causative and analytic causative.

In Indonesian language, analytic causative construction can be formed by such verbs as membuat 'make', menyebabkan 'cause', mengizinkan 'allow', memerintahkan 'order', and menyuruh 'ask'. Such a construction is very productive because Indonesian language consists of a combination of several regional languages so that it is interesting to examine the similarities and differences in the causative construction of the Indonesian language and the related regional languages. One of them is Javanese language which is mainly spoken in Java Island and has spread to various provinces across the country in various dialects, including to the province of North Sumatra in a certain dialect. Based on the level of speech, Javanese can be divided into three main strata namely Ngoko Javanese, Madya Javanese and Krama Javanese (Wedhawati 2006: 11). Ngoko is the Javanese language, which is used as the source of data in this research. It is frequently spoken by Sumatran people known as Deli Javanese 
dialect for daily conversation in informal situation.

Furthermore, in Javanese there are also three types of causative construction as proposed by Comrie (1989) covering analytic causative, lexical causative and morphological causative. The verbs are to express their causer and causee as depicted in the Javanese language like the word nggawe 'make' and marakake 'cause'. The construction of the cause with the verb nggawe is different from that with marakake. The use of the verb nggawe in causative construction implies an action with a will, while the use of the verb marakake does not indicate an action with a will. In this research, the lexical causative is not analyzed because it simply contains general meaning not as the other two. In the analytic causative construction in Javanese the suffix used in the verb carries a similar meaning. In addition, this language uses separate verbs that express their causer and causee as in the following example.

1. Bejo nggawe tetongone sengsoro.(analytic causative)

Bejo nggawe.ACT tetonggo.POSS sengsoro

'Bejo makes his neighbors miserable'

2. Bejo nyengsoroke tetonggone. (morphological causative)

Bejo sengsoro. ACTtetonggo.POSS

'Bejo torments his neighbors'

3. Bejo ngganggoni tetonggone. (lexical causative)

Bejo nggangngoni.ACT tetonggo.POSS

'Bejo disturbs his neighbors'

Sentence (1) is an analytic causative which consists of two predicates: nggawe 'make' and sengsoro 'miserable', while sentence (2) is a morphological causative because this sentence uses morphological markers or prefix ny- and suffix -ke to change a non-causative verb to become causative. Whereas, sentence (3) is a lexical causative because one predicate already contains the idea of cause and effect.

Based on the explanation above, this research discusses: 1) the form of morphological and analytic causative construction in Deli Javanese dialect, and 2) the process of forming a morphological and analytic causative construction in the language. This analysis is seriously done to provide linguistic knowledge on the forms of morphological and analytic causative construction in the language under research.

\section{Literature Review}

\subsection{Causative Concept}

The concept of causative construction is expressed by Goddard (1998: 266) who states that causative construction is an expression which contains an event that is caused by someone's actions or because something happened. The concept of causative is also given by Artawa (2004: 48) who states that almost every language has its own way of forming or expressing causative construction. In general, causative construction describes a micro or event consisting of (1) the event of causee that causes an event and (2) the event that occurs or the result happens caused by the action of causee (Shibatani, 1976: 239, Comrie, 1989: 330).

Generally, causativity in several languages in the world occurs on three basic clauses, namely the intransitive basic clause, the monotransitive basic clause, and the transitive basic clause (Comrie, 1989). In each part, the different relation shifting occurs after experiencing a 
causative process. In this case, relation is the relationship between verbs and arguments that are respectively interdependent in the structure of the clause. The causativity event was described by Comrie (1988) and Purwiati (2012) as follows:

Tabel 1. Alteration of Valence of Non-causative Basic Verbs to Causative Verbs

\begin{tabular}{|c|c|c|}
\hline Type of Clause & Non-Causative Basic Verbs & Causative Verb \\
\hline Intransitive & SUBJ - & SUBJ \\
\hline Monotransitive & $\begin{array}{l}\text { SUBL } \\
\mathrm{OL}-\end{array}$ & $\begin{array}{l}\text { SUBJ } \\
\text { OL } \\
\text { OTL } \\
\end{array}$ \\
\hline Distransitive & $\begin{array}{l}\text { SUBJ } \\
\text { OLL }\end{array}$ & $\begin{array}{l}\text { SUBJ } \\
\text { OL } \\
\text { OTL }\end{array}$ \\
\hline
\end{tabular}

\subsubsection{Morphological Causative Construction}

Morphological causative construction is characterized from the verb makes use of a prefix or/and a suffix, for example in Ndari nyenengke mbakyune 'Ndari makes her elder sister happy'. The suffix -ke is a marker of morphological causative construction. Furthermore, in Deli Javanese dialect, an example of morphological causative construction is generally depicted as follows:

(1). a. Suratman nggodoke wedang kanggo dayohe. 'Suratman boiled drinking water for his

guest.'

b. Bapak ngeleboke kereto. 'Father put into the house someone's motorbike.'

The verb nggodoke shows that wedang 'drinking water' in (1a) is a target that becomes direct object of the verb nggodoke 'boiled something for someone', and dayohe 'his guest' is the indirect object, which is preceded by the preposition kanggo 'for'. In the sentence (1b), the verb ngeleboke 'put into the house' has the direct effect to the object kereto 'motorbike'.

\subsubsection{Analytic Causative Construction}

Analytic causative construction consists of two predicates or verbs, which function as predicate 1 and predicate2. In accordance with the example below, in Deli Javanese dialect, predicate1 is filled with the verb nggawe 'make' or marakke 'cause', and predicate2 is a condition, process, or verb that performs an action or results in an event. Nggawe and marakke causative verbs differ semantically in the sense that with the verb nggawe 'make', the event that occurs is caused by the desired action, whereas with the verb marakke, the action on the causer is undesirable. It can be depicted in the following examples:

(2). a. Ponirin nggawe bojone sengsoro. 'Ponirin makes his wife suffer'

b. Nindi marakke tokone ambrok. 'Nindi causes the shop to collapse.' 
The verb nggawe in sentence (2a) shows that the predicate has an indirect object bojone 'his wife'. It seems that the meaning of the sentence is wider compared with the form of morphological causative as Ponirin nyengsoroke bojone 'Ponirin makes his wife suffer'. In sentence $(2 \mathrm{~b})$ the predicate shows an action done unpurposely or undesirably. The two sentences have the same patten in grammatical SVOV. In other words, between predicate1 and predicate 2 there are noun phrases (NP) as the grammatical objects of the causative verbs.

\subsection{Types of Causative Construction}

The types of causative constructions that each language has are different from each other. Some languages have all the three types of causative construction (lexical causative, morphological causative and analytic causative) and some languages have only two types of causative construction; lexical causative and analytic causative. Languages that have all the three types of constructions generally belong to agglutinative language type because this type of language has affixes that can be attached to a verb that function to increase or decrease the valence of the verb. Meanwhile, a language that has only two types of causative construction is a type of language known as isolating because the language in general does not have an affix that functions to increase or decrease the valence of the verb.

Goddard (1998: 266) explains that causative construction is an expression which contains an event that is caused by someone's action or because something happens. Opinions about causative construction are also expressed by Artawa (2004: 48), which reveals that almost every language has a unique way of forming or expressing causative construction. In general, a causative construction is a construction that describes a macro-complex situation that contains two micro situations or events consisting of (1) causee of events that cause an event to occur and (2) events that occur or the effect caused by the action of causee (Shibatani 1976: 239, Comrie, 1989: 330).

In this research, it is necessary to describe the syntactic categories of the language under discussion as this is concerned with a syntactic approach. Syntactic categories refer to the types of syntactic units that theories of syntax assume, known as parts of speech or word classes in traditional theory. In generative grammar, a syntactic category is symbolized by a node label in a constituent structure tree. The forms of syntactic categories can be listed below as composed by O'Grady (1997: 169), and divided into two categories:

\begin{tabular}{ll} 
Lexical Catagories & Non-Lexical Catagories \\
\hline Noun (N) & Determiner (Det) \\
Verb (V) & Degree Word (Deg) \\
Adjective (A) & Auxiliary (Aux) \\
Proposition (P) & Conjunction (Conj)
\end{tabular}

One of the most common ways to create a visual representation of syntactic structure is through tree diagrams. Symbols (Art=article, $\mathrm{N}=$ noun, NP = noun phrase) are used to label the parts of the tree to capture the hierarchical organization of those parts in the underlying structure of phrases and sentences.

Baker (1998) defines that "Tree diagrams are used quite widely in scholarly works and textbooks. Their major justification is that they provide quick and efficient representations of some important organizational properties of individual sentences". Tree diagram depicts the representation of syntactic structure as shown below: 


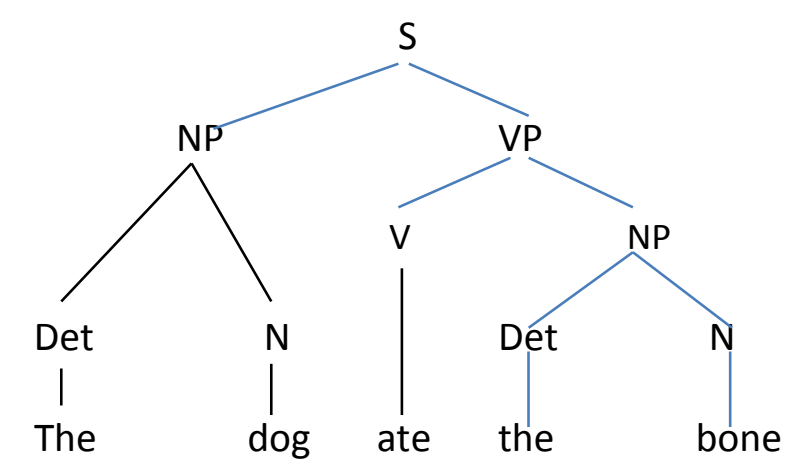

(Baker, 1998)

\section{Research Method}

The method used in this study is called marking techniques. The markers indicate the occurrence of certain lingual units or constituents and the ability to read the role of the markers themselves to determine the intended event. The practice of its use is very typical, not using tools as other techniques but rather seeing the markers directly concerned, which can be done syntactically. Besides corporal markers, there are other types of markers, which are not specifically related to each form but cover many different lingual forms with the same pragmatic intent as there are varied voices of adventure. Therefore, this study uses the marking technique as a research method and morphological causative construction as the basis for determining the marker. Furthermore, this research includes data collection and data analysis. The research begins with the process of capturing data, collecting, identifying and classifying them. Furthermore, the data that have been classified are analyzed with the appropriate steps. To find out the use of the causative construction in Javanese sentences, we need data that supports the analysis. Therefore, this study began with data collection and continued with the data analysis to achieve the objectives of this study. To broaden the understanding on the analysis result, it is necessary to design a tree diagram based on its syntactic categories of each finding that follows the concept of Brake (1998) and O'Grady (1997).

\section{Result and Discussion}

\subsection{Morphological Causative}

As stated by Whaley (1997: 194-195), the degree of causativity is the movement from indirect to direct, following the sequence of Analytical-morphological-lexical causative construction. When using certain morphological devices, for example affixation, the construction is morphological causative (Comrie 1989: 167). The Morphological causative constructions were found in the sentence below.

(1). Paiman mateni lampu.

PaimanACT.mati lampu.

'Paiman turned off the lamp.'

The suffix - $n i$ is a marker of morphological causative construction. The subject Paiman is the agent which is followed by a transitive verb mateni 'switch off' with the objet lampu 'lamp' as the patient. The verb mateni has a direct effect to the object lampu.

a. Gurunotok mejo karo tangane.

Gurutotok mejo prep tangan-poss.

'The teacher hit the table with his hand.' 
b. Guru notoke tangane nang mejo.

Guru notok+Caus tangan+poss prep mejo.

'The teacher hit his hand on the table.'

2. (a) Guru Notok mejo karo tangane.

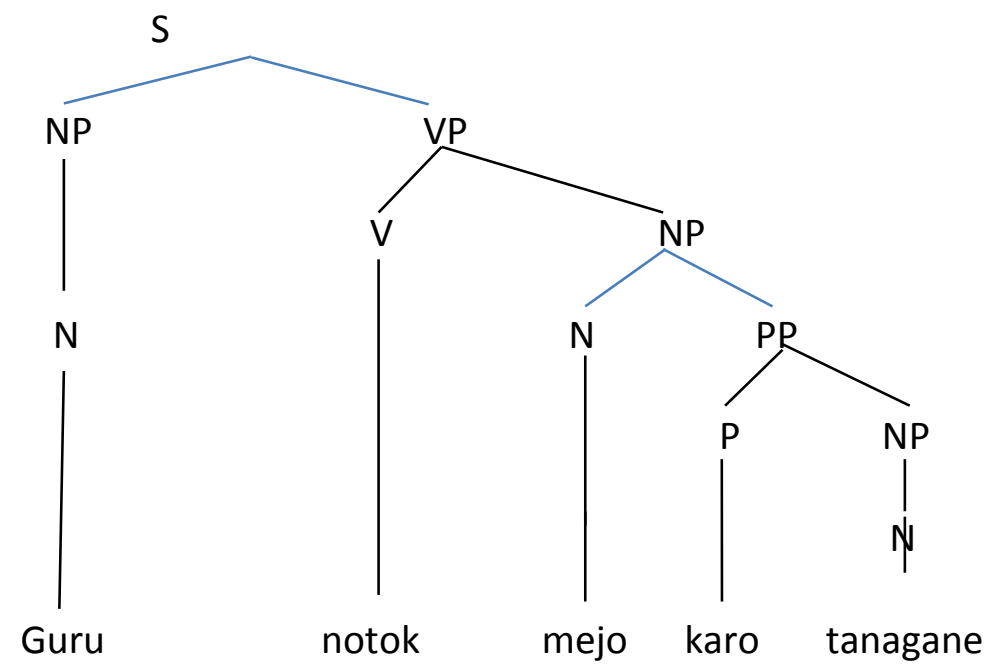

(b) Guru notokke tangane nang mejo.

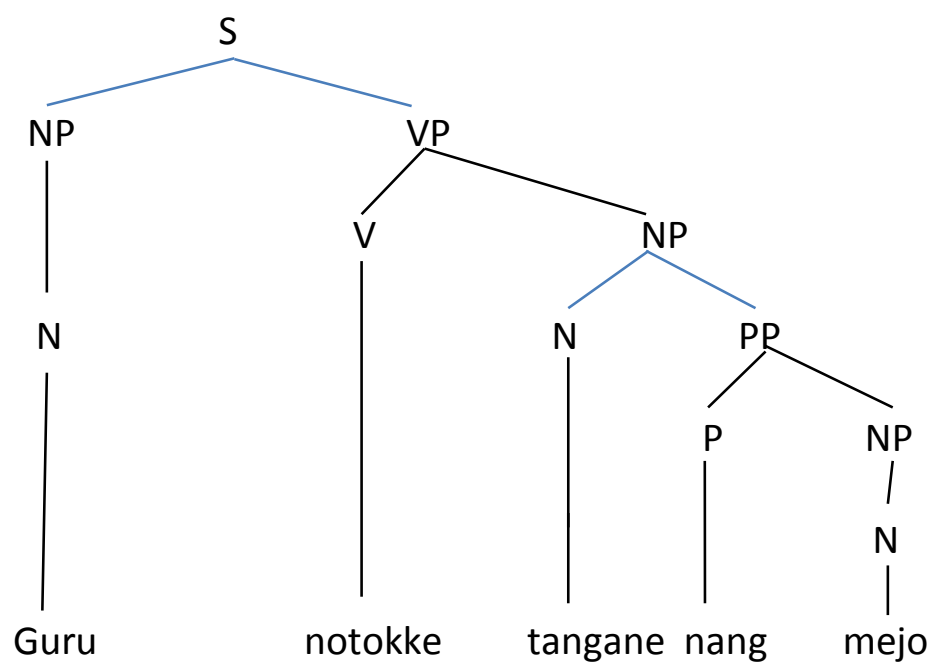

The verb notok shows that mejo (2a) is a target that becomes a direct object, whereas the verb notoke, the target which formally becomes a direct object is tangane. There is a change in the verb form morphologically in which the word notok is added by suffix -e to become nototke. It shows that the morphological causative contsruction occurs. It is also similar to example (1) which also shows a causative construction that distinguishes concretely, whose target formally becomes a direct objec, but it has no affixes on the verb. In Deli Javanese dialect, this becomes important because there is a direct/nonsemantic effect, like the following finding:
a. Bapak tuku lereng baru kanggo Bejo.
BapakACT. lerengbaru PREP Bejo. 
'Father bought a new bicycle for Bejo.'

b. Bapak nukokake Bejo lereng baru.

BapakACT.tuku Bejo lereng baru.

'Father bought Bejo a new bicycle.'

3. (a) Bapak tuku lereng baru kanggo Bejo.

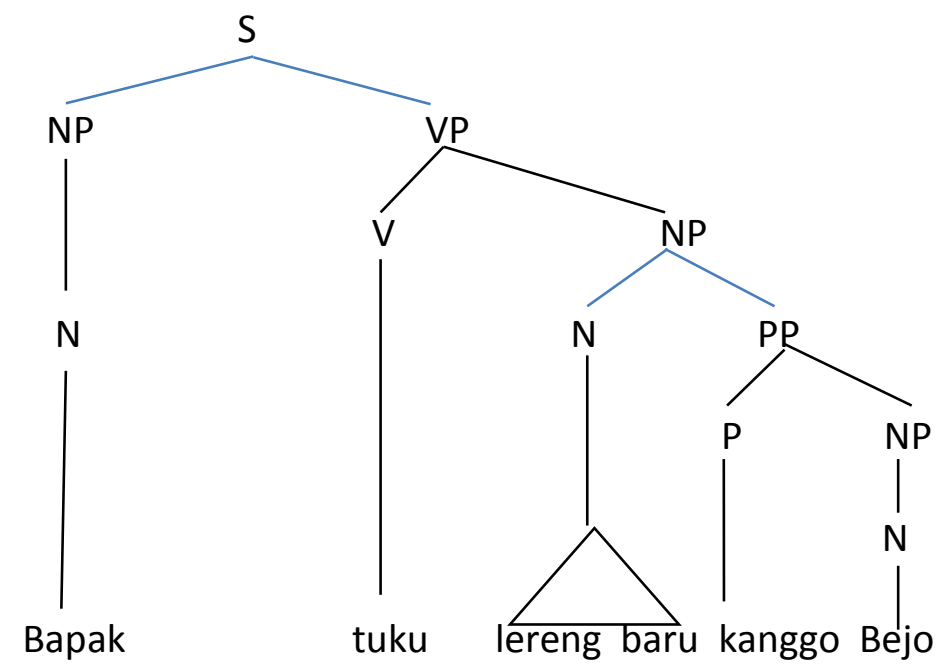

(b) Bapak nukokake Bejo lereng baru.

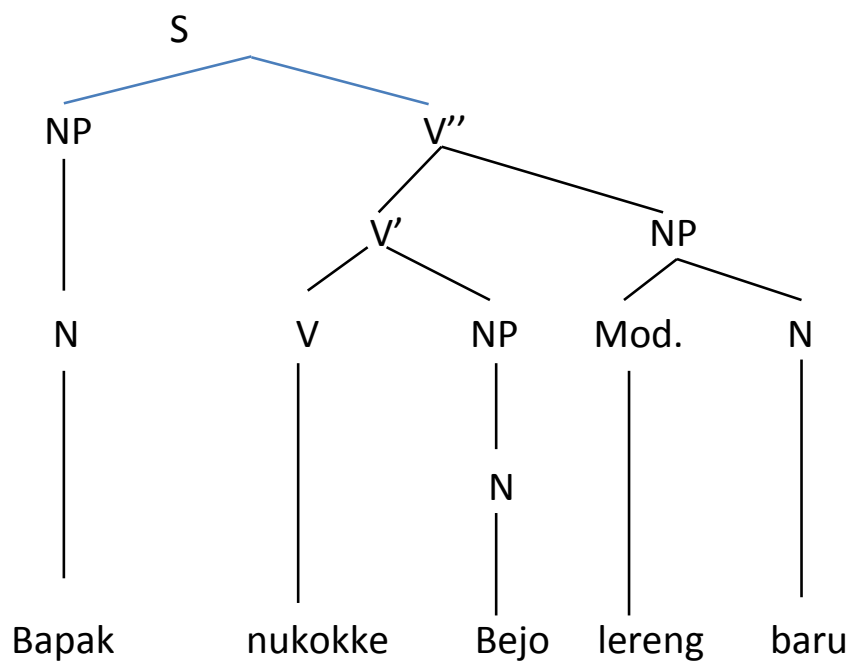

If analyzed through a valence sequence converter (Whaley 1997: 188), the direct object in (3a) is lereng, while (3b) is Bejo. The problem is that kanggo bejo in (3a) can be removed, while the NP lereng baru in (3b) cannot be eliminated. Here, it means that there is no addition of valence. Syntactically gawe bejo in (3a) becomes optional. Thus, (3a) has 2 arguments, while (3b) has 3 arguments. The relationship with the causee accessibility hierarchy is that (3a) has the following pattern; (3a) ibune> lereng baru, while (3b) ibune> Bejo> lereng baru. Deli Javanese dialect also describes a construction of intransitive pattern. Does it also show a direct effect semantically? Let us see the following findding:

(4) Dokter ngombekne obat kanggo pasiene.

DokterACT.ngombe obat PREPpasien-DEM.

'The doctor took the madicine to her patients.' 


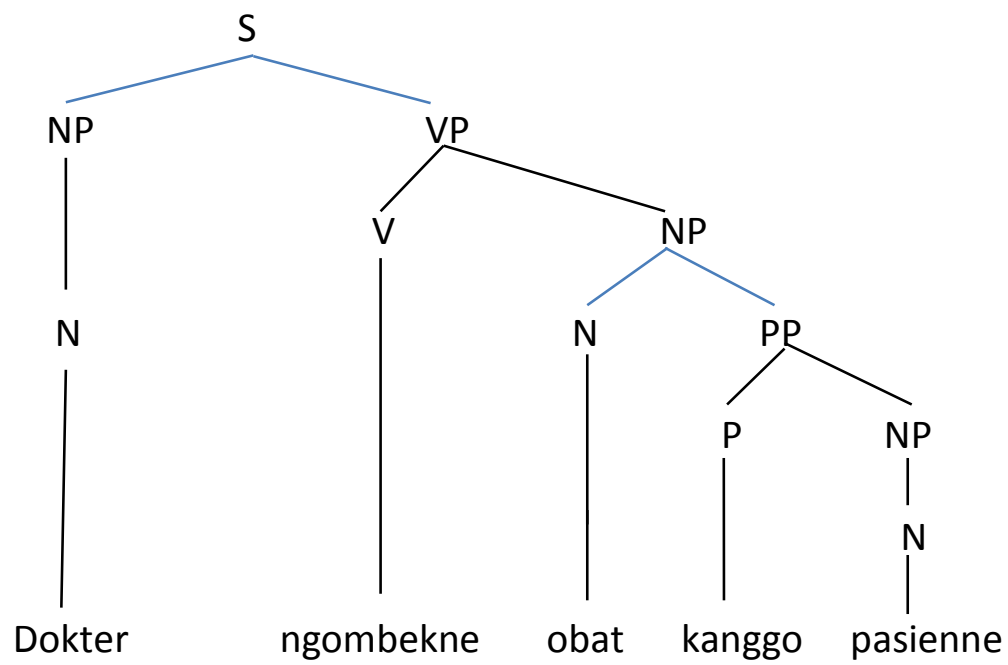

The suffix -ne in ngombekne is a marker of morphological causative construction. In this case, Dokter is the agent for the patient of the word obat and it becomes the first object as well. Pasiene is the second object, which is preceded by the preposition kanggo. The word ngombekne is a transitive verb, which gives an immediate effect. Similar to example (4), the following example is a sentence pattern with verbs that undergo a morphological causative construction.

(5) Pak Mahmud nggawe Budi dadi menejer.

Pak MahmudACT. Gawe Budi ACTmenejer

'Mr. Mahmud made Budi become manager.'

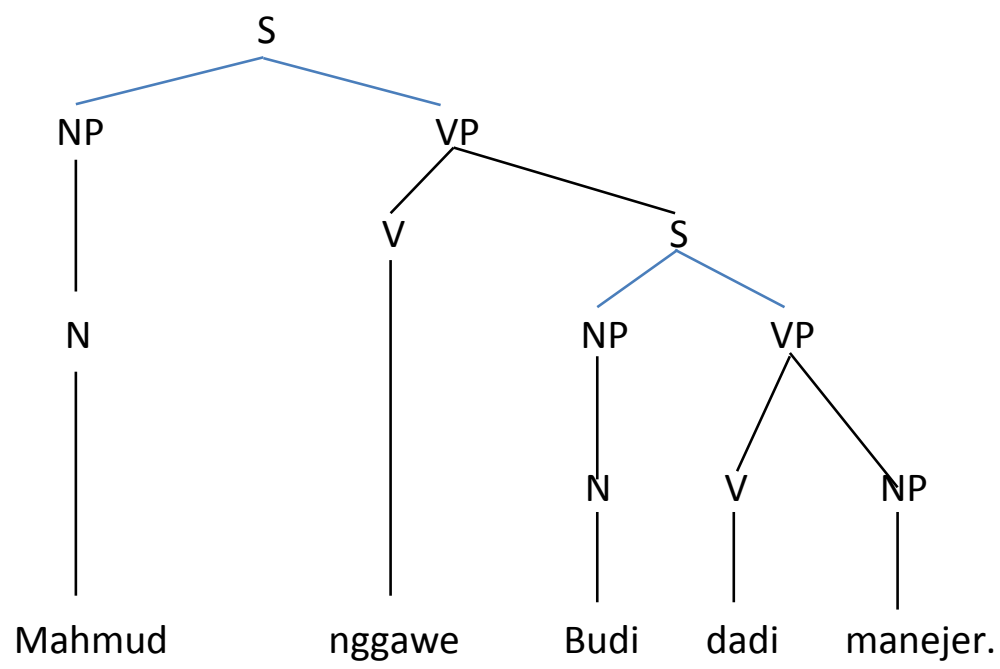

Semantically, nggawe contains an immediate effect. Budi is the first object, while the menejer is the second object. Although the word nggawe and jadi show the cause and effect likely occuring in the sytactic causative construction, it also depicts the form of morphological causative with the affixes of the verb nggawe in which it derives from the word gawe becomes nggawe with the prefix -ng. The level of control is very large in the morphological causative verb.

\subsection{Analytic Causative}

Analytic causative construction is a causative construction which has a predicate that expresses cause and effect, the cause is expressed by a word separated from the word that 
shows what is caused (Comrie, 1989: 165--171). The forms of analytic causative were found as follows:

1. a. Joko teko nang pesta.

JokoACT PREP pesta.

'Joko came to the party.'

b. Raden nggawe Joko teko nang pesta.

RadenACT. Gawe Joko ACT PREP pesta.

'Raden made Joko come to the party.'

1. (a) Joko teko nang pesta.

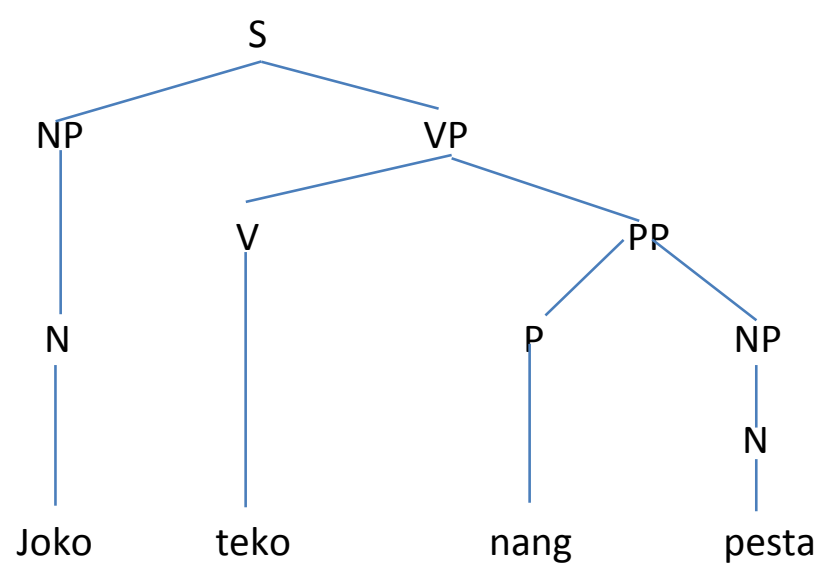

(b) Raden nggawe Joko teko nang pesta.

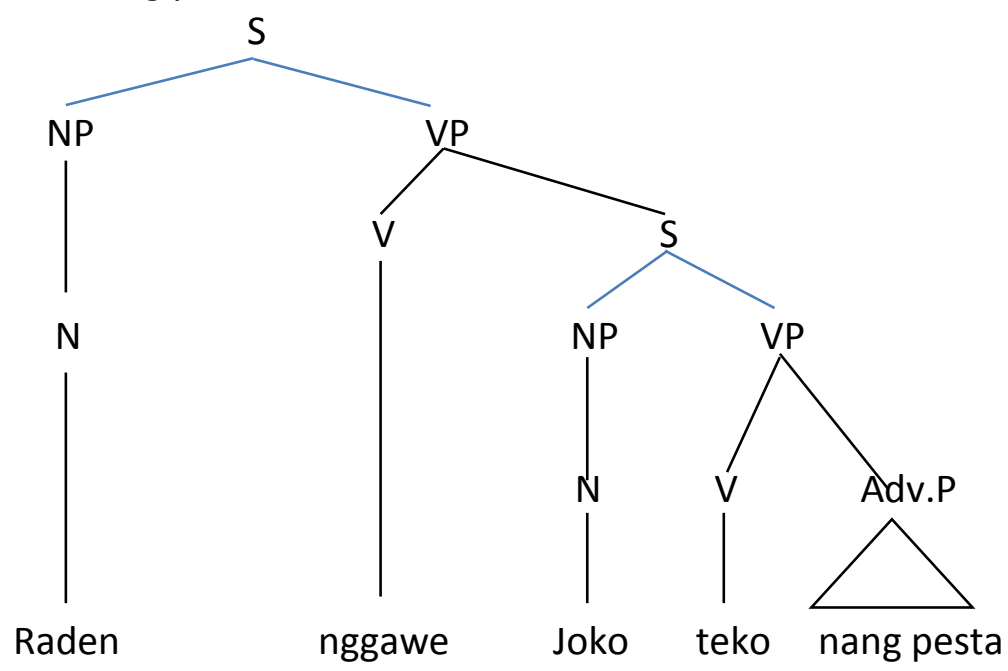

2. a. Murid nggoleki gurune

Murid ACT.golek guru-DEM

'The students look for the teacher.'

b. Tugas omah nggawe murid nggoleki gurune

Tugas omahACT.gawe muridACT. golek guru-DEM

'The homework made the students look for the teacher.'

2. (a) Murid nggoleki gurune. 


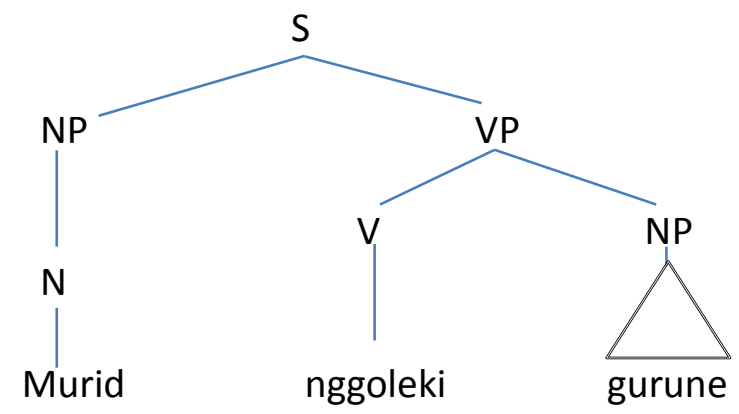

(b) Tugas omah nggawe murid nggoleki gurune.

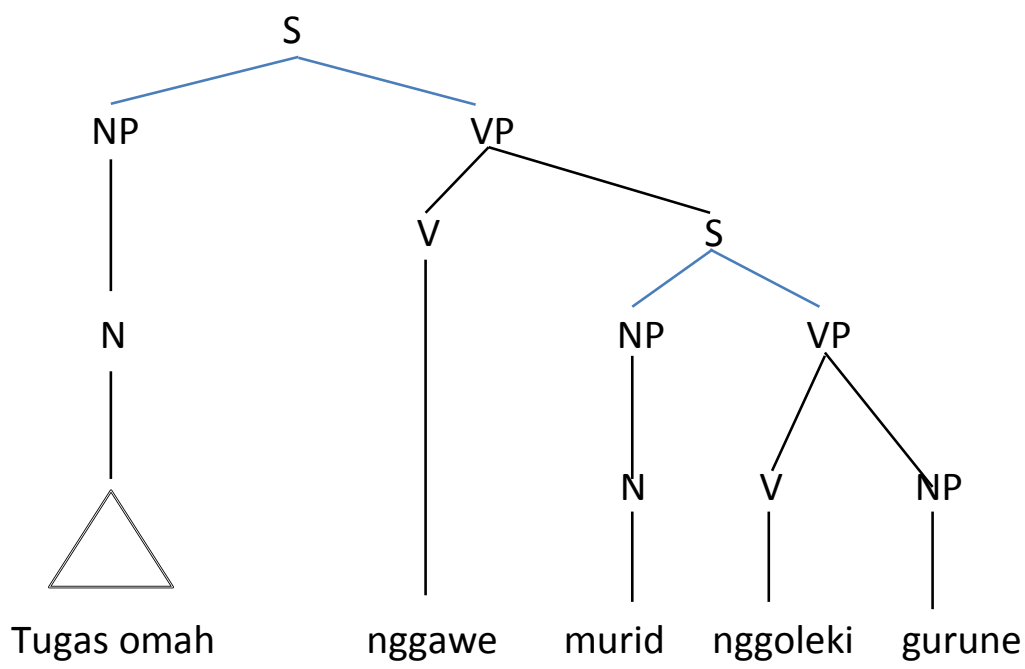

Based on the finding above it can be seen that the causative construction in (1-b) and $(2-b)$ is formed from the noncausative construction (1-a) and (2-a). From the type of predicate, the noncausative construction (1-a) makes use of an intransitive verb, while the noncausative construction (2-a) makes use of a transitive verb. Observe that the change from noncausative construction with an intransitive verb (1-a) and with a transitive verb (2-a) to causative construction (1-b) and (2-b) requires the presence of causative verbs nggawe. The presence of the causative verb nggawe causes analytic causative construction with two different predicates in each construction. The effect of adding a causative verb is the addition of an argument that functions as a causer. The presence of the verb nggawe in sentence (1-b) demands the presence of the word Raden as a causer so that it raises the result of Joko teko nang pesta. Likewise, with sentence (2-b), the causative verb nggawe causes tugas omah 'homework' causes something to students so that murid nggoleki gurune 'the student look for the teacher'.

3. a. Pandi nggawe ibu bungah. PandiACT.gawe ibu bungah

'Pandi makes mother happy.'

b. Pandi nggawe bungah ibu. PandiACT.gawebungahibu.

'Pandi makes happy to mother.'

(a) Pandi nggawe ibune bungah. 


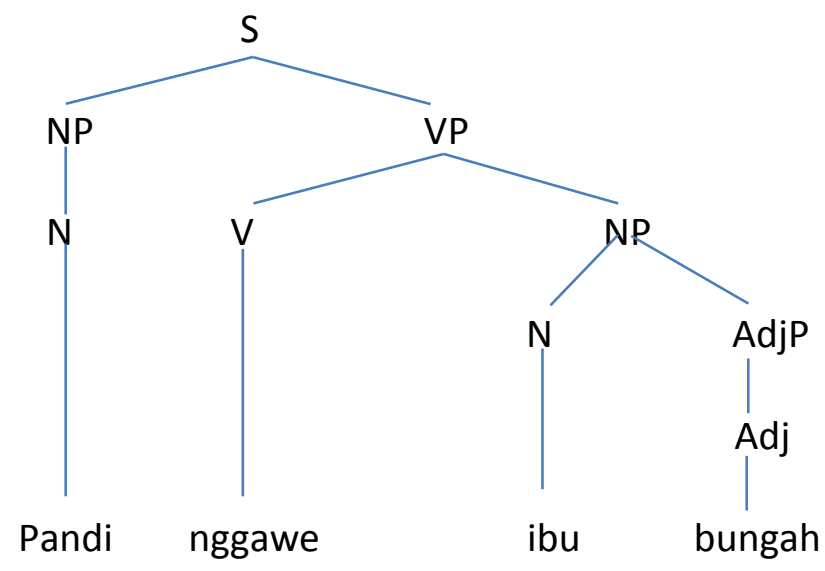

(b) Pandi nggawe bungah ibune.

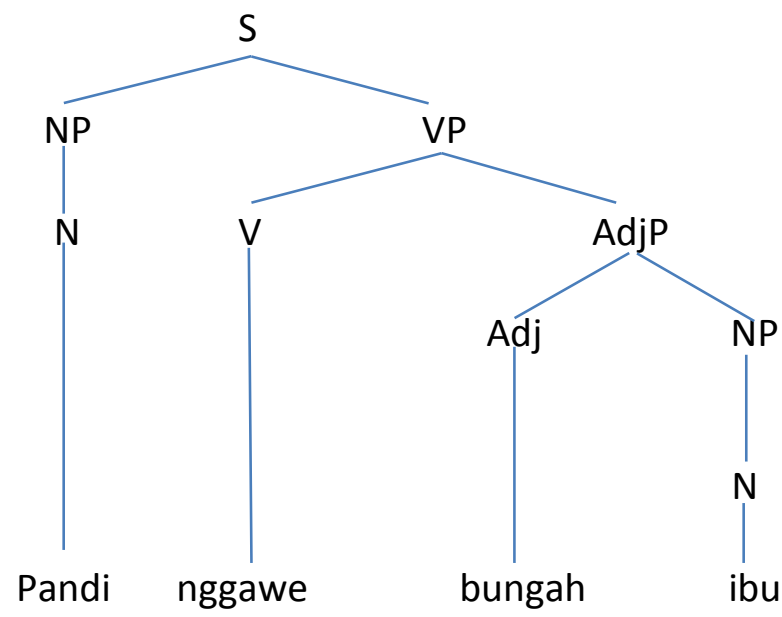

Analytic causative construction in Javanese usually has an SVOV word order; the same happens to most other ethnic languages in Indonesia. In other words, between predicate 1 and predicate 2 there is a noun phrase to be the grammatical object of the causative verb. However, when the predicates use verbs with the intention to convey as the word bungah, then the predicate2 can be immediately paired after the predicate1, resulting in SVVO pattern which is a variation of the canonical pattern of SVOV word order.

\section{Conclusion}

In Deli Javanese dialect, causative construction has a few forms in its process. After decribing the process, it is concluded that morphological causative construction implies that the meaning of cause and effect is indicated by prefixes and suffixes as in the verbs mati 'die' and mateni 'kill' it is indicated by the suffix -ni. On the other hand, analytic causative construction in Deli Javanese dialect can be formed by using the verbs nggawe 'make', a verb stating a cause either a condition or an action verb. The use of the verb nggawe in a causative construction implies an action with an intention. Analytic causative construction in Javanese is a 'biclause' construction. In general analytic causative construction can be formed with more productive causative verbs, such as make, cause, allow, order and ask. From the categories, the analytic causative construction in Javanese has two verbs, the one in the noncausative construction which is the basis for the formation of analytic causative construction and the other one in the causative construction which can be in the form of intransitive verbs, transitive verbs, adjectives, and nouns. The emergence of a cause and effect 
component explicitly makes it easy to identify micro situations in analytic causative construction.

\section{References}

Artawa, Ketut. (2012). The basic verb construction in Balinese. In Alexander Adelaar (Ed.) Voice variation in Austronesian language of Indonesia. NUSA 54, 5-27.

Artawa, Ketut. (2004). Balinese Language: Typological Description. Denpasar: CV. Bali Media Adhikarsa.

Baker, L. (1998). English Syntax. London: The MIT Press.

Comrie, B. (1989). Language Universal and Linguistic Typology. Oxford: Blackwell.

Goddard, Cliff. (1998). Semantic Analysis: A Practical Introduction. Oxford : Oxford University Press.

O'Grady, William. (1997). Syntactic Development. Chicago: University of Chicago Press.

Purwati, I. (2012). Sistem konstruksi kausatif bahasa Bali. In Jurnal Widyaparwa, Vol. 40, 6978.

Shibatani, M. (Ed). (1976). Syntax and Semantics. The Grammar of Causative Constructions. New York: Academic Press.

Wedhawati, Nurlina, Setiyanto (Ed). (2006). Tata Bahasa Jawa Mutakhir. Jakarta: Departemen Pendidikan Nasional.

Whaley, Lindsay J. (1997). Introduction to Typology: The Unity and Diversity of Language. USA: Sage Publication. 